Literature Review

\title{
Effectiveness of core stability exercise for knee joint osteoarthritis: A review
}

\author{
Muhammad Deyu Wisnubrata ${ }^{1 *}$, Rahmat Sayyid Zharfan ${ }^{2}$ \\ 1) Medical Doctor, Staff of Faculty of Medicine Universitas Muhammadiyah Surabaya, \\ 2) Medical Doctor, Soekandar General Hospital Mojokerto
}

\begin{tabular}{ll} 
A R T I C L E & I N F O \\
\hline Submitted & : July 2019 \\
Accepted & : September 2019 \\
Published & : January 2020 \\
\hline
\end{tabular}

Keywords:

core stability exercise, joint, knee, osteoarthritis

\section{*Correspondence:}

deyuwisnubrata@yahoo.com

\begin{abstract}
The knee joint is a weight-bearing support joint that often affected by osteoarthritis. Knee joint osteoarthritis is characterized by pain in a movement that disappears when resting, joint stiffness especially after prolonged resting or waking up, crepitations, and can be accompanied by synovitis with or without joint fluid effusion. If the patient was passive, did not do exercises, muscle atrophy can occur, which will worsen the stability and function of the joint. Other consequences that can disrupt daily activities to the most severe feature, such as an inability to walk. To discuss the role of core stability exercise for pain reduction in osteoarthritis. This type of study is a literature review. The goals of core stability exercise include: increasing muscle strength, improving posture, reducing pain, increasing ability, and functional mobility in patients. The provision of core stability exercise has a relationship between core stability with hip, knee, and ankle. This is because all parts of the body are connected to each other, both directly and indirectly. If the core muscle is strong, the muscles of the hip, knee, and ankle will also be strong. Core stability exercise is potential in the management of knee osteoarthritis
\end{abstract}




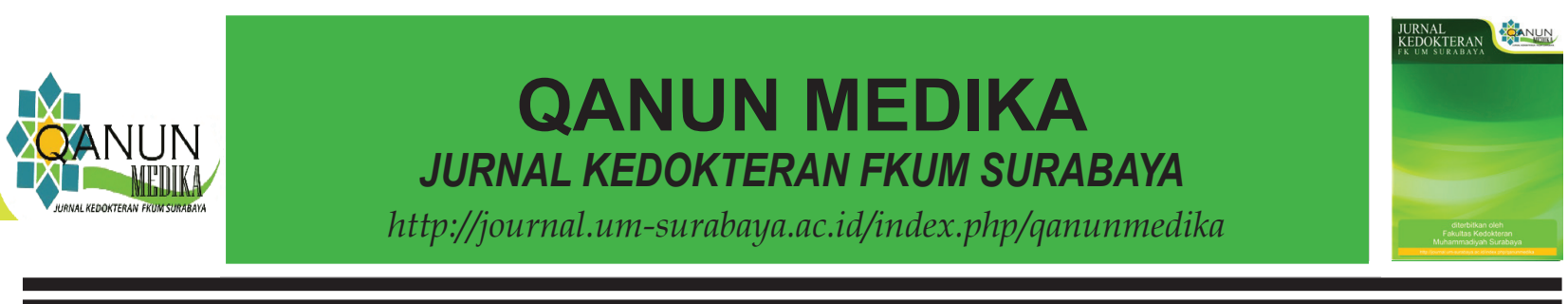

\section{INTRODUCTION}

Osteoarthritis is a chronic joint disease that often occurs in the world, especially in the elderly. The prevalence of osteoarthritis in Indonesia is also quite high as $5 \%$ at age $>$ 40 years old, $30 \%$ at age $40-60$ years old, and $65 \%$ at age $>61$ years old. This disease is experienced by $10 \%$ of men and $13 \%$ of women overall aged over 60 years (Zhang \& Jordan, 2011). Osteoarthritis mainly attacks the waist and knees in the bones and joints in the area. The cartilages between the joints serve as a cushion when the joint is worn, but because this part is damaged, the bone surfaces in the joints collide with each other so that it causes pain, swelling, and stiffness (Hamijoyo, 2012).

According to the Indonesian Rheumatology Association, Osteoarthritis is defined as a degenerative joint disease that occurs due to chronic inflammatory processes in the joints and bones around the joints. This causes the bones to become brittle and become porous. Some risk factors for OA are trauma, obesity, heredity, and age (Hamijoyo, 2012).

Osteoarthritis (OA) included as a degenerative joint disease with a complex etiology that results in loss of normal joint function due to damage to the articular cartilage (Loeser, Goldring, Scanzello, \& Goldring, 2013). The knee joint is a weight-bearing support component which often affected by osteoarthritis. Knee joint osteoarthritis is characterized by pain in a movement that disappears when resting, joint stiffness, especially after prolonged resting or waking up, crepitations, and can be accompanied by synovial inflammation, with or without joint fluid effusion. If the patient only had passive activity, does not want to do training, muscle atrophy can occur, which will worsen the stability and function of the joint. Other consequences that can disrupt daily activities ranging from pain when sitting to the most severe feature like walk difficulty (Valderrabano \& Steiger, 2011).
Pain is a clinical symptom that is often found in patients with knee osteoarthritis, especially when doing activities or weight-bearing movement. As a result of knee osteoarthritis is a decrease in functional activity, especially difficulty from getting up to sitting, walking, going up and downstairs, and others (Sharma et al., 2015). Various kinds of treatment can be given in this case, including medical drugs administration, non-steroidal anti-inflammatory drugs, surgery, and physiotherapy. Treatment that is often given is non-steroidal antiinflammatory drugs (NSAIDs) that are used to treat complaints of pain and inflammation. The use of this drug in the long term can have adverse effects (Steinmeyer et al., 2018).

Core stability exercise describes the ability to control or control the position and central movements of the body. Core stability exercise activities will help maintain good posture in motion and be the basis for all movements of the arms and legs. This shows that with optimal posture stability (activation of the Core Stability muscles), mobility in the upper and lower limbs can be done efficiently (Yu \& Park, 2013). The purpose of this study was to review the role of core stability exercise in the management of knee osteoarthritis

\section{LITERATURE REVIEW}

\section{OSTEOARTHRITIS (OA)}

Osteoarthritis is a non-inflammatory degenerative joint disease that mainly occurs in older people, characterized by degeneration of joint cartilage, bone hypertrophy at the edges, and changes in the synovial membrane ( $\mathrm{Li}$ et al., 2013). Secondary osteoarthritis experienced before the age of 45 years is usually caused by trauma (instability) that causes injuries to the joints (e.g., broken joint surfaces) due to loose joints and surgery on the joints. Other causes of osteoarthritis are genetic factors and metabolic diseases (Yucesoy et al., 2015). Pain is the most common complaint submitted by sufferers of 
OA patient, especially in joints supporting weight, pain when walking, especially when going up and downstairs, pain when not doing activities, mainly at night often occurs in patients with OA, but the more severe the disease, the pain will appear only with minimal joint movement, even when resting (Hunter et al., 2008). Clinically OA is manifest into various levels such as subclinical, with no clinical signs found. Only pathologically can be found an increase in the amount of cartilage tearing, the formation of bull/blister and fibrillation fibers of collagen connective tissue in joint cartilage (Man \& Mologhianu, 2014), whereas in the subchondral bone sclerosis occurs. According to the afferent theory consists of 2 groups of fibers namely large fibers (A-Beta) and small fibers (A-delta and $C$ ). The mechanism of pain through exercise therapy, namely: exercise therapy is one of the treatments in physiotherapy that in practice uses body movements both actively and passively so that it can accelerate the healing of injuries of osetoarthritis or other diseases that have changed normal lifestyle (Tashani \& Mi, 2009).

\section{OA treatment}

In patients with $\mathrm{OA}$ in the knee joint, what is complained of is a deep pain in the knee and is getting worse when the patient is doing activities, especially when walking, going down the stairs, and getting up from his seat (Hernandez et al., 2019). For this reason, treatment of Osteoarthritis aims to reduce pain and improve physical function and quality of life of patients in their daily activities. Some treatments for patients with Osteoarthritis are:

\section{Lifestyle modification}

One risk factor for OA is obesity. Weight loss in patients with knee osteoarthritis can reduce the symptoms of pain caused by the disease. Of course, this can be achieved if the patient is able to exercise well and regularly. Also, exercise can help regulate muscle strength (Woolf, 2010).
Conservative therapy that can be done includes education to patients, lifestyle settings; if the patient is obese, they must reduce weight, if possible, keep exercising (light exercise options such as cycling, swimming) (Bliddal, Leeds, \& Christensen, 2014).

\section{Pharmacotherapy}

Paracetamol is a group of non-steroidal antiinflammatory drugs proven to reduce the symptoms of pain that arise and become the first line in the treatment of osteoarthritis. Giving intra-articular glucocorticoids can eliminate joint effusion due to inflammation, hyaluronic acid, and chondroitin sulfate is believed to significantly reduce pain around several weeks after injection (Aydogdu, Karakose, Celik, \& Atesci, 2014).

\section{Surgical approach}

Surgical therapy can be performed on patients with severe pain and does not respond to conservative therapy or pain that causes substantial functional disability and affects lifestyle. Some joints, especially knee joints, can be replaced with artificial joints. Surgery can improve joint function and movement and reduce pain. Among the surgeries that can be done if the treatments cannot respond appropriately or are ineffective in osteoarthritis patients are Arthroscopy, Osteotomy, and Arthroplasty (Katz, Earp, \& Gomoll, 2010).

\section{Physical therapy}

Physical therapy for OA patients includes traction, stretching, transverse friction (special massage techniques for patients with OA), muscle stimulation exercises, and the latest approach is through core stability exercise (Hoglund, Pontiggia, \& Kelly, 2018). 


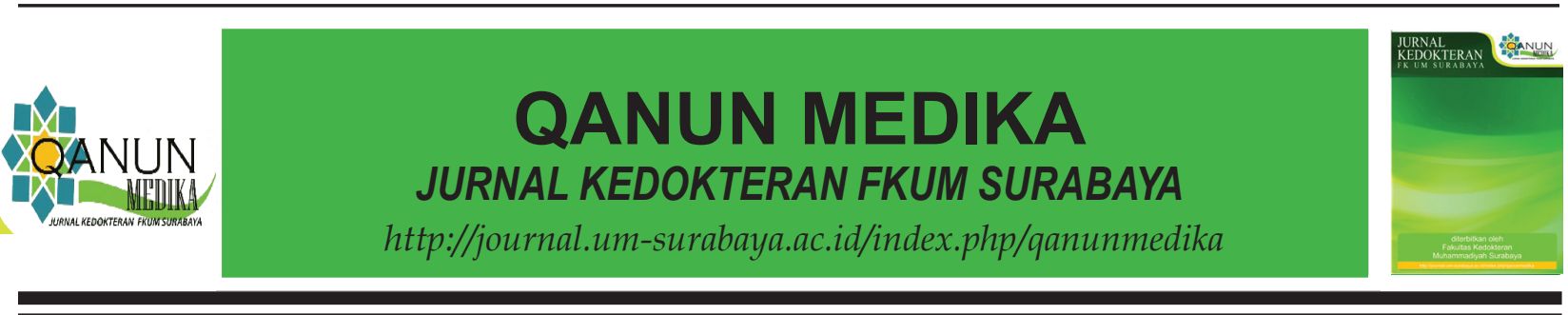

\section{Anatomy of Core Stability Muscle}

Core muscle generally is interpreted as a muscle where the center of gravity of the body (center of gravity) is located, and all movements in the body originate from the core muscles. Core muscles support the entire movement and balance of the human body (Sadeghia, Shariata, Asadmanesh, \& Mosavat, 2016).

Specifically, the core muscle is the structure of the muscles that support the entire structure of the spine, abdomen, pelvis, and pelvis, or what is referred to as LPHC (Lumbo-Pelvic Hip Complex). Strong core muscles are useful for maintaining the balance of the proportion of the body's muscles in doing the whole kinetic chain of our body movements. In the dynamic motion of the human body, the core muscles control the efficiency of acceleration/ deceleration movements and stabilize the body to prevent injury (Shah \& Varghese, 2014).

The core muscles cover the abdominal trunk to the bottom of the torso. Muscles in this area include the Gluteus Muscle Group (buttock muscles, middle hip, and hamstring or back muscles of the thigh), Hip Muscle Group (upper and pelvic hips), Abdominal Muscle Group (front and side abdominal muscles, oblique or waist area muscles ), Spine Muscle Group (muscles in the backbone area) (Kibler, Press, \& Sciascia, 2006).

Core stability exercises as a form of exercise that aims to form and strengthen the main muscles in the lower back and pelvis, where these muscles play a significant role in maintaining stability and balance in the body. Core stability exercise is a synergistic activation exercise that contracts the stabilizer of the core muscle muscles consisting of travel sum abdominus, rectus abdominus, multifidus, internal oblique, and external oblique muscles. Strong core muscle can improve balance and stability with good stability center of mass (COM), and center of gravity (COG) can be held above the base of support (BOS) the best balance is when the center of mass and center of gravity are maintained above the base of support resulting in an increase in postural and increased productivity (Kisner \& Colby, 2011).

\section{Core Stability Exercise (CSE)}

"Core" terminology refers to a lumbopelvichip complex, muscular area consisting of the muscles of abdominal, paraspinal, gluteus, diaphragm, pelvic girdle, and pelvic floor. This muscular complex controls the position of the trunk and plays the leading role in pelvic movements. The "core" as a source of force production, and as the kinetic chain that transfers and control motion until the distal part of the body (Hernandez et al., 2019).

Core stability exercise is defined as an exercise to improve neuromuscular ability. This exercise is intended to increase control than lumbopelvic. This increase in lumbopelvic can be done in two ways, namely, first, increasing the coordination and control of the lumbopelvic muscles and second, increasing the strength of the lumbopelvic muscles (Pardis, Mahla, Ali, Maryam, \& Ramin, 2018). The core stability exercise model is based on spinal stability, depending on the contribution of muscles. In other words, muscle activity is needed to maintain the position of the spine. Many muscles are in the lumbopelvic and contribute to spinal control and stability.

In the core stability, the focus is to re-train the function of deep muscle (transverse abdominus and multifidus) and integrate the activity of deep muscle and global muscle in their work (Chang, Lin, \& Ping-Tung Lai, 2015). Coordinated deep muscle is very important in the movement of the intervertebral segments of the spine and pelvis, although these muscles do not contribute significantly to the spine but are very important to stabilize the spine. The 
effect of core stability training will develop the work of the dynamic muscular corset muscles. With the onset of a contraction coordinated and concurrent (co-contraction) of these muscles will provide colander rigidity to support the trunk, consequently intradiscal pressure is reduced and will reduce the workload of the lumbar muscles and lower extremity such: hip and knee joint, so that tissue is not easily injured, abnormal lumbar muscle tension is reduced (Javadian, Akbari, \& Talebi, 2015). With the occurrence of muscle relaxation, it is expected that there will be an improvement in the muscle pump which results in increased blood circulation to the back muscle tissue. Thus the supply of nutrition and oxygen in the muscle tissue to be better, the pain caused by spasm will be reduced.

\section{The Procedure of Core Stability Exercise}

Core stability training is intended to train the muscles related to the balance of the core in our body. That way, to increase these muscles needed systematic and programmed training and must follow the existing training program. This exercise will also be more effective if done with our body position in accordance with the body's biomechanics (Bliven \& Anderson, 2013).

Core stability exercise is an exercise program that emphasizes the existence of stretching and strengthening of the core between the pelvis and vertebra. This exercise is also an essential component in providing local strength and balance in maximizing activities to be more efficient. The types of core stability exercises include 5 types: (1) seated abdominal contraction, (2) seated oblique twist, (3) legs lift, (4) bridge exercise, and (5) lying spinal rotation (Suadnyana, Nurmawan, \& Muliarta, 2014). Core stability exercises that can increase muscle strength will ultimately improve the postural balance of the elderly. This exercise can be done 4-6 weeks with a frequency of 3 times a week (Hoglund, Pontiggia, \& Iv, 2018; Chevidikunnan, Saif, Gaowgzeh, \& Mamdouh, 2016).

\section{Evidence of Core Stability Exercise in Knee Osteoarthritis Treatment}

There is a vicious circle in osteoarthritis-related to pain, physical dysfunction, and muscle weakness. Where muscle weakness is related to pain, it leads to physical dysfunction, thereby affecting disease progression. Core muscle exercise plays a vital role in the management of knee osteoarthritis.

Electronic searches of published literature were conducted from 2015 to the latest literature. Search strategies used in the search term 'core stability exercise'; "osteoarthritis ';' knee '; We apply the following algorithm in Pubmed, Google Scholar, and free text words: "(core stability exercise) AND osteoarthritis ';' AND knee." 


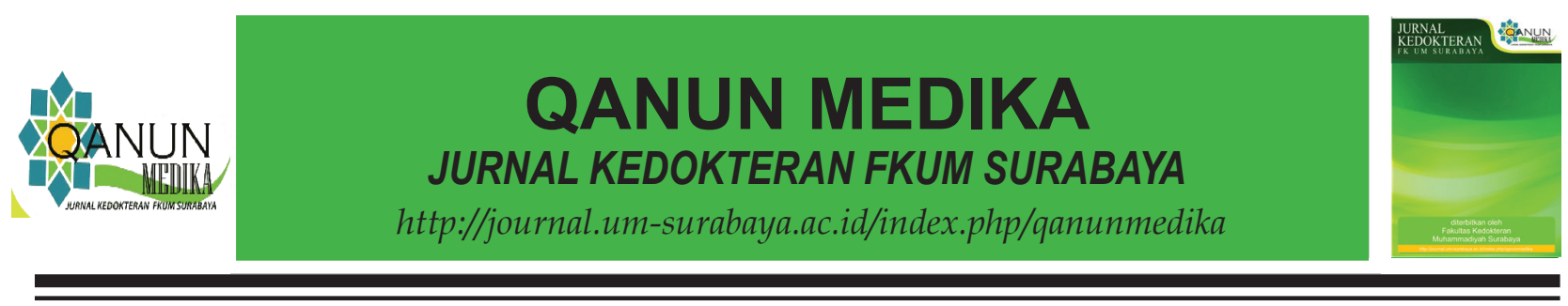

Table 1. List of core stability exercises in knee OA evidence

\begin{tabular}{|c|c|c|}
\hline Author; year & Type of Study & Result \\
\hline $\begin{array}{l}\text { Dabholkar } \\
\text { (2016) }\end{array}$ & $\begin{array}{l}\text { Correlation } \\
\text { experimental } \\
\text { design }\end{array}$ & $\begin{array}{l}\text { A study of } 19 \text { patients with knee osteoarthritis, } \\
\text { underwent core muscle strength was assessed } \\
\text { using pressure biofeedback apparatus. There is a } \\
\text { significant correlation of the core stability } \\
\text { measures with the functional activity level in } \\
\text { knee osteoarthritis. }\end{array}$ \\
\hline $\begin{array}{l}\text { (Chevidikunna } \\
\text { n et al., 2016) }\end{array}$ & $\begin{array}{l}\text { Quasi- } \\
\text { experimental } \\
\text { study }\end{array}$ & $\begin{array}{l}\text { Study of } 20 \text { female patients ( } 16 \text { - } 40 \text { y.o with } \\
\text { patellofemoral pain syndrome, and given four } \\
\text { weeks given an additional core muscle } \\
\text { strengthening. There is a significantly higher } \\
\text { improvement in the intensity of pain and } \\
\text { dynamic balance }\end{array}$ \\
\hline $\begin{array}{l}\text { Hoglund et al. } \\
\text { (2018) }\end{array}$ & $\begin{array}{l}\text { Pre-post } \\
\text { intervention } \\
\text { design, pilot } \\
\text { study }\end{array}$ & $\begin{array}{l}\text { Study of } 10 \text { females with Patellofemoral Joint } \\
\text { (PFJ OA). PFJ OA patients underwent ten twice- } \\
\text { a-week hip strengthening and core stabilization } \\
\text { exercise sessions. The participants reported the } \\
\text { improvement of pain, symptoms, daily living } \\
\text { function, sports activity, and quality of life all } \\
\text { improved within six weeks. }\end{array}$ \\
\hline $\begin{array}{l}\text { Subramanian } \\
\text { \& Suganthi } \\
(2017)\end{array}$ & Case study & $\begin{array}{l}\text { Subject aged } 87 \text { years knee with osteoarthritis } \\
\text { was treated with specific core exercises during } \\
\text { the period of } 6 \text { months with weekly twice } \\
\text { frequency. A reduction in BMI }(\mathrm{P}<0.05) \text { and } \\
\text { Womac osteoarthritis index }(\mathrm{P}<0.05) \text { with } \\
\text { significant statistical analysis }\end{array}$ \\
\hline $\begin{array}{l}\text { Zarei \& } \\
\text { Rahnama, } \\
(2017)\end{array}$ & $\begin{array}{l}\text { Quasi- } \\
\text { experimental } \\
\text { study }\end{array}$ & $\begin{array}{l}\text { Twenty-five women with knee osteoarthritis } \\
\text { performed core exercises for eight weeks, and } \\
\text { each consisted of } 3 \text { sessions. A significant } \\
\text { increase was observed in the static and dynamic } \\
\text { balances, the score of fear of falling ( }<<0.001) \text {. }\end{array}$ \\
\hline Khisty (2019) & $\begin{array}{l}\text { Pre - post } \\
\text { experimental } \\
\text { study }\end{array}$ & $\begin{array}{l}\text { Thirty patients with unilateral medial } \\
\text { tibiofemoral osteoarthritis of the knee. The } \\
\text { patients underwent core exercise training } \\
\text { included three types of exercises: static } \\
\text { abdominal contractions, pelvic bridging, } \\
\text { abdominal crunches. There was a statistically } \\
\text { significant difference in Knee Injury, and } \\
\text { Osteoarthritis Outcome Score (KOOS) } \\
\text { questionnaire Score and Visual Analogue Scale } \\
\text { (VAS) post the intervention }(\mathrm{p}<0.05)\end{array}$ \\
\hline
\end{tabular}


Effect of Core Stability Exercise in Knee Osteoarthritis

Knee Osteoarthritis is known to be associated with a decrease in muscle strength and atrophy of the muscles that stabilize this joint. Core stability training can improve the coordination and stability of the trunk, pelvis, hips, and knees by stimulating the crucial muscles of the lumbopelvic-hip complex and the periarticular muscles of the knee. Appropriate training programs that aim to regain muscle strength have been shown to have the potential to protect joints against pathological stressors (Hernandez et al., 2019).

Core stability exercise will develop the work of dynamic muscular, with the occurrence of coordinated and concomitant contractions of these muscles will provide rigidity to support the trunk, resulting in reduced intradiscal pressure and will reduce the workload of the lumbar muscles and lower extremity, so that the surrounding tissue is not easily injured, abnormal lumbar muscle tension is reduced (Kisner \& Colby, 2011). With the stretching of the muscles, it is hoped that there will be an improvement in the muscle pump which results in increased blood circulation to the back muscle tissue. Thus the supply of blood and oxygen in the muscle tissue to be better so that the pain caused by spasm will be reduced. Besides activating the core muscles that function as spinal stabilizer muscles will make the surrounding muscles that had been spasms relaxed, thus also obtained excellent spinal stability and the position of the spine in a neutral state (Kisner \& Colby, 2011). Good spinal stability will be more comfortable for a person to do functional activities. Besides, reduced intradiscal pressure will make it easier for patients to perform functional activities. Among other patients will be easier to carry out activities of lifting, walking, sitting, standing, and when doing recreational activities.
Core Stability is the ability to control the position and motion of the trunk to the pelvis, which is used to make an optimal movement with the transfer of body weight and stepping during the process of walking. The activation of the core muscles is used for resulting in spine rotation. Increased core stability activation patterns also result in increased levels of activation of the extremities or limbs to develop capabilities to support or move the extremities. Which will help maintain good posture in motion and be the basis for all movements of the arms and legs (Kibler et al., 2006).

\section{CONCLUSION}

According to the literature review, it has been shown that core stability exercise is potential in the management of knee osteoarthritis. Several studies have proven that core stability exercise is effective in reducing pain and improving physical function in patients with osteoarthritis of the knee.

\section{REFERENCES}

Aydogdu, O., Karakose, A., Celik, O., \& Atesci, Y. Z. (2014). World Journal of Clinical Pediatrics, 3(1). https://doi.org/10.5409/ wjcp.v3.i1.1

Bliddal, H., Leeds, A. R., \& Christensen, R. (2014). Osteoarthritis, obesity, and weight loss : evidence, hypotheses, and horizons - a scoping review. Obesity Reviews, (6). https://doi.org/10.1111/ obr.12173

Bliven, K. C. H., \& Anderson, B. E. (2013). Core Stability Training for Injury Prevention. Sports Health, 85206. https:// doi.org/10.1177/1941738113481200

Chang, W.-D., Lin, H.-Y., \& Ping-Tung, Lai. (2015). Core strength training for patients with chronic low back pain. $J$ Phys Ther Sci, 14-17. 


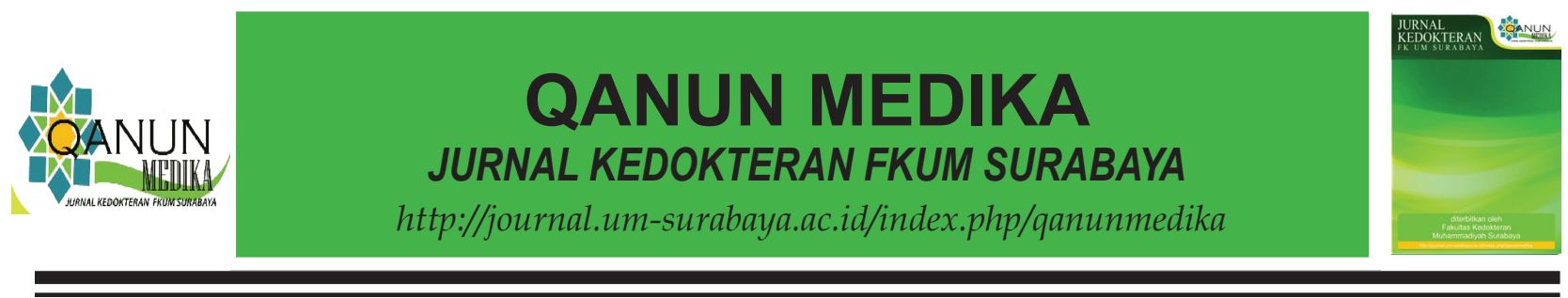

Chevidikunnan, M. F., Saif, A. Al, Gaowgzeh, R. A., \& Mamdouh, K. A. (2016). Effectiveness of core muscle strengthening for improving pain and dynamic balance among female patients with patellofemoral pain syndrome. $J$ Phys Ther Sci, 28, 1518-1523.

Dabholkar, T. A., \& Dabholkar, A. (2016). Correlation of the core stability measures with the hip strength and functional activity level in knee osteoarthritis. IJTRR, 5(January). https://doi.org/10.5455/ijtrr.000000180

Hamijoyo, L. (2012). Pengapuran Sendi Atau osteoarthritis. Retrieved from http:// reumatologi.or.id/reujurtail id $=22$

Hernandez, D., Dimaro, M., Navarro, E., Dorado, J., Accoce, M., Salzberg, S., \& Oscar, P. (2019). Journal of Bodywork \& Movement Therapies Ef fi cacy of core exercises in patients with osteoarthritis of the knee : A randomized controlled clinical trial. Journal of Bodywork \& Movement Therapies (XXXX). https:// doi.org/10.1016/j.jbmt.2019.06.002

Hoglund, L. T., Pontiggia, L., \& Iv, J. D. K. (2018). A 6-week hip muscle strengthening and lumbopelvic-hip core stabilization program to improve pain, function, and quality of life in persons with patellofemoral osteoarthritis : a feasibility pilot study. Pilot and Feasibility Studies, 1-14.

Hoglund, L. T., Pontiggia, L., \& Kelly, J. D. (2018). A 6-week hip muscle strengthening and lumbopelvic-hip core stabilization program to improve pain, function, and quality of life in persons with patellofemoral osteoarthritis : a feasibility pilot study. Pilot and Feasibility Studies (April). https://doi. org/10.1186/s40814-018-0262-z
Hunter, D. J., Mcdougall, J. J., Keefe, F. J., England, N., Hospital, B., Ave, P. H., \& Ma, B. (2008). The symptoms of OA and the genesis of pain. Rheum Dis Clin North Am, 34(3), 1-19. https://doi.org/10.1016/j. rdc.2008.05.004.The

Javadian, Y., Akbari, M., \& Talebi, G. (2015). Influence of core stability exercise on lumbar vertebral instability in patients presented with chronic low back pain: A randomized clinical trial. Caspian J Intern Med, 6, 98-102.

Katz, J. N., Earp, B. E., \& Gomoll, A. H. (2010). Surgical Management of Osteoarthritis Jeffrey. Arthritis Care Res (Hoboken), 62(9), 1220-1228. https://doi.org/10.1002/ acr.20231.Surgical

Khisty, A. (2019). Effect Of Core Stability Exercises In Patients With Unilateral Osteoarthritis Of Knee. International Journal of Innovative Knowledge Concept, $7(5)$.

Kibler, W. Ben, Press, J., \& Sciascia, A. (2006). The Role of Core Stability in Athletic Function. Sport Med, (June 2014). https:// doi.org/10.2165/00007256-20063603000001

Kisner, C., \& Colby, L. (2011). Therapeutic Exercise: Foundation and Techniques. (Fifth Edit). Philadelphia: F. A. Davis Company, 1915 Arch Street.

Li, G., Yin, J., Gao, J., Cheng, T. S., Pavlos, N. J., Zhang, C., \& Zheng, M. H. (2013). Subchondral bone in osteoarthritis : insight into risk factors and microstructural changes. Arthritis Research \& Therapy, $15,223$.

Loeser, R. F., Goldring, S. R., Scanzello, C. R., \& Goldring, M. B. (2013). Osteoarthritis: A Disease of the Joint as an Organ. Arthritis Rheum, 64(6), 1697-1707. https://doi. org/10.1002/art.34453.Osteoarthritis 
Man, G., \& Mologhianu, G. (2014). Osteoarthritis pathogenesis - a complex process that involves the entire joint. Journal of Medicine and Life, 7(1), 3741.

Pardis, N., Mahla, K., Ali, M. M., Maryam, A.-F., \& Ramin, K. (2018). The Role of a Multi-Step Core Stability Exercise Program in the Treatment of Nurses with Chronic. Asian Spine Journal, 12(7), 490-502.

Sadeghia, H., Shariata, A., Asadmanesh, E., \& Mosavat, M. (2016). The Effects of Core Stability Exercise on the Dynamic Balance of Volleyball Players. International Journal of Applied Exercise Physiology, 3(October 2013).

Shah, D. N., \& Varghese, A. (2014). Effect of Core Stability Training on Dynamic Balance in Healthy Young Adults - A Randomized Controlled Trial. Int $J$ Physiother, 1(4), 187-194. https://doi. org/10.15621/ijphy/2014/v1i4/54563

Sharma, L., Chmiel, J. S., Almagor, O., Moisio, K., Chang, A. H., Belisle, L., Hayes, K. W. (2015). Knee Instability and Basic and Advanced Function Decline in Persons with Knee Osteoarthritis. Arthritis Care Res (Hoboken), 67(8), 1095-1102. https:// doi.org/10.1002/acr.22572.Knee

Steinmeyer, J., Bock, F., Stöve, J., Jerosch, J., Flechtenmacher, J., Hospital, J. E., Community, O. (2018). Pharmacological treatment of knee osteoarthritis : Special considerations of the new German guideline. Orthopedic Reviews, 10. https://doi.org/10.4081/or.2018.7782

Suadnyana, I. A. ., Nurmawan, S., \& Muliarta, I. M. (2014). Core Stability Exercise Meningkatkan Keseimbangan Dinamis Lanjut Usia di Banjar Bebengan, Desa Tangeb, Kecamatan Mengwi, Kabupaten Badung. Thesis Universitas Udayana.
Subramanian, S. S., \& Suganthi, S. (2017). Impact of Core Exercises and Alignment Correction Exercises of Bilateral Osteoarthritis Knee on an Octogenarian Subject - Evidenced Study. Case Studies Journal, 6(7), 9-14.

Tashani, O., \& Mi, J. (2009). Transcutaneous Electrical Nerve Stimulation ( TENS ) A Possible Aid for Pain Relief in Developing Countries? Libyan J Med, 62-65. https://doi.org/10.4176/090119

Valderrabano, V., \& Steiger, C. (2011). Treatment and Prevention of Osteoarthritis through Exercise and Sports. Journal of Aging Research, 1216. https://doi.org/10.4061/2011/374653

Woolf, C. J. (2010). What is this thing called pain? The Journal of Clinical Investigation, 120(11), 3742-3744. https://doi.org/10.1172/JCI45178

Yu, S., \& Park, S. (2013). The effects of core stability strength exercise on muscle activity and trunk impairment scale in stroke patients. Journal of Exercise Rehabilitation, 9(3), 362-367.

Yucesoy, B., Charles, L. E., Baker, B., Burchfiel, C. M., Branch, M. B., Effects, H., Safety, O. (2015). Occupational and genetic risk factors for osteoarthritis: A review. Work, 50(2), 261-273. https://doi.org/10.3233/ WOR-131739.Occupational

Zarei, P., \& Rahnama, N. (2017). Comparison of the Effects of the Two Strengthening and Balanced, Strengthening, Balanced, and Core-stability Exercise Protocols on the Balance and Fear of Falling in Women with Knee Osteoarthritis. JPSR, 7.

Zhang, Y., \& Jordan, J. M. (2011). Epidemiology of Osteoarthritis Yuqing. Clin Geriatr Med, 26(3), 355-369. https://doi. org/10.1016/j.cger.2010.03.001. Epidemiology 